\title{
Diagnoza i usprawnianie słuchu fonematycznego i fonetycznego
}

\section{Diagnosis and improvement of phonemic and phonological hearing}

\author{
Anna Kruczyńska, Zdzisław Marek Kurkowski \\ Uniwersytet Marii Curie-Skłodowskiej, Zakład Logopedii i Językoznawstwa Stosowanego, Lublin \\ Adres autora: Anna Kruczyńska, Uniwersytet Marii Curie-Skłodowskiej, Zakład Logopedii i Językoznawstwa \\ Stosowanego, ul. Sowińskiego 17, 20-040 Lublin, e-mail: anna.kruczynska@umcs.pl
}

\begin{abstract}
Streszczenie
Słuch fonematyczny jest jednym z elementów warunkujących odbiór i rozumienie mowy. W przypadku jego zaburzenia niezbędne jest przeprowadzenie testów, które dadzą odpowiedź, jak duży jest stopień tego deficytu oraz co powinno być istotne w programowaniu terapii logopedycznej, a także które dźwięki mowy nie są przez pacjenta różnicowane.

W niniejszej pracy przedstawiono istotę zaburzenia słuchu fonematycznego, dokonano przeglądu testów do jego diagnozy, dostępnych zarówno w Polsce, jak i na świecie, oraz istniejących metod terapii, wykorzystywanych przez logopedów i pedagogów w pracy z dziećmi mającymi trudności w tym zakresie.
\end{abstract}

Słowa kluczowe: słuch fonematyczny • dyskryminacja słuchowa $\bullet$ terapia logopedyczna

\begin{abstract}
Phonemic hearing is one of the prerequisites for the reception and speech intelligibility. In case of its disorder, it is necessary to conduct tests that will reveal how big is the level of the deficit and, what is important in speech therapy programming, which speech sounds are not differentiated by the patient.

In this paper, the essence of phonemic hearing impairment was presented together with a review of tests for its diagnosis, available both in Poland and in the world, and existing therapy methods, used by speech therapists and educators working with children who have difficulty in this area.
\end{abstract}

Key words: phonemic hearing • auditory discrimination • speech therapy

\section{Wprowadzenie}

W polskiej literaturze panuje spore zamieszanie dotyczące terminologii związanej $\mathrm{z}$ różnicowaniem i identyfikowaniem dźwięków mowy. W odniesieniu do tego zagadnienia używa się takich pojęć jak słuch: fonematyczny, fonemowy, fonologiczny, fonetyczny oraz słuch mowny. Stosowanie tak wielu pojęć niesie za sobą zarówno różne interpretacje samego zagadnienia, jak i różne działania praktyczne stosowane $\mathrm{w}$ terapii.

Najczęściej używanym terminem jest jednak 'słuch fonematyczny', przeniesiony na grunt polski z radzieckiej szkoły - posługiwał się nim wybitny psycholog A. R. Łuria. W Polskiej literaturze termin ten za J. T. Kanią oznacza „umiejętność oceny bodźców językowych z punktu widzenia potrzeb komunikacji językowej, tj. umiejętność percypowania (wyodrębniania oraz identyfikowania) elementów fonologicznie relewantnych (istotnych), pomijania zaś cech dla procesu porozumiewania się redundantnych (nieistotnych)" [1].

Z kolei Bronisław Rocławski wprowadza dwa terminy słuch fonemowy i fonetyczny. Słuch fonemowy, określany wcześniej jako fonologiczny, definiuje jako „zdolność do kwalifikowania wyróżnionych z potoku mowy głosek jako przynależnych do określonych, fonologicznie zdeterminowanych klas głosek, czyli fonemów". W definicji Rocławskiego istotne są dwa terminy: 'wyróżnianie' i 'kwalifikowanie' głosek. Termin 'kwalifikowanie’ należy rozumieć jako identyfikowanie głoski (przypisanie jej do określonego fonemu), z kolei 'wyróżnianie' jako wyodrębnianie. Hasło 'słuch fonetyczny' wyjaśnia jako „umiejętność spostrzegania cech prozodycznych oraz różnic między głoskami 
należącymi do tej samej klasy (stanowiącymi ten sam fonem)" [2]. Wskazuje na związek tej umiejętności ze słuchem muzycznym. Zdolność różnicowania elementów prozodycznych mowy należałoby raczej określić terminem 'słuch prozodyczny'.

Irena Styczek podobnie jak J. Kania używa terminu 'słuch fonematyczny’. Zwraca w swojej definicji szczególną uwagę na umiejętność rozróżniania dźwięków na podstawie cech dystynktywnych oraz podkreśla znaczenie najważniejszej zdolności - rozróżniania wyrazów, która kształtuje się w oparciu o umiejętność rozróżniania i utożsamiania najmniejszych elementów składowych wyrazów, czyli fonemów.

W anglojęzycznej literaturze nie używa się terminów 'słuch fonematyczny, fonetyczny, fonologiczny', zatem nie występuje tak wielkie zamieszanie terminologiczne, $\mathrm{z}$ jakim mamy do czynienia w Polsce. Opisując zagadnienie różnicowania i identyfikowania dźwięków mowy, stosuje się przede wszystkim termin 'dyskryminacja słuchowa' (ang. auditory discrimination).

Dyskryminację słuchową definiuje się podobnie jak słuch fonematyczny w Polsce. Słuchowa dyskryminacja jest to zdolność rozpoznawania różnic pomiędzy fonemami (najmniejszymi jednostkami dźwiękowymi w języku), w tym zdolność do oceny takich samych i różnych dźwięków i słów [3].

Słuch fonematyczny jest podstawowym elementem percepcji mowy. Jego zaburzenia wywołują szereg trudności, mogą przyczyniać się do utrudnień lub całkowitego uniemożliwienia odbioru mowy, zaburzeń rozwoju wymowy lub zaburzeń wymowy już ukształtowanej, a także do trudności w nabywaniu umiejętności czytania i pisania lub powodować zaburzenia tych umiejętności już ukształtowanych [4].

W przypadku lżejszych zaburzeń wskazują na trudność w identyfikowaniu jednej opozycji, np. dźwięczne-bezdźwięczne. Słowa różniące się dwiema lub większą liczbą cech dystynktywnych w przypadku lżejszych zaburzeń nie przysparzają większych trudności w zakresie ich odróżniania. Większe deficyty mogą powodować szereg problemów z identyfikacją dźwięków mowy różniących się dwiema i większą liczbą cech dystynktywnych. Głębokie zaburzenia mogą całkowicie uniemożliwiać różnicowanie dźwięków mowy [5].

Zaburzenia słuchu fonetycznego wiążą się przede wszystkim $\mathrm{z}$ trudnościami $\mathrm{w}$ różnicowaniu różnych wariantów tych samych głosek, takie problemy związane są przede wszystkim $\mathrm{z}$ autokontrolą słuchową.

Zaburzenia słuchu fonematycznego występują nie tylko $\mathrm{u}$ dzieci, lecz także u dorosłych, dzieje się tak np. w przypadku afazji. Trudności u pacjentów tego typu wynikają z uszkodzenia drugorzędowych pól słuchowych [6].

\section{Wybrane testy diagnostyczne}

W celu zbadania zdolności rozróżniania, identyfikowania i różnicowania dźwięków stworzono specjalne testy.
W Polsce dostępne są cztery testy do badania tych umiejętności (tabela 1).

\section{Badanie i kształtowanie słuchu fonematycznego (I. Styczek, 1982)}

Pierwszą opracowaną techniką badawczą jest próba wyrazowa, sylabowa i literowa do badania słuchu fonematycznego, zawarta w publikacji „Badanie i kształtowanie słuchu fonematycznego" autorstwa Ireny Styczek.

Próba literowa, przeznaczona dla dzieci potrafiących pisać, polega na wysłuchaniu prezentowanych przez badającego głosek, a następnie wskazaniu ich odpowiedników w postaci liter.

Próbę sylabową można przeprowadzić na trzy różne sposoby. Podajemy dziecku podobne brzmieniowo sylaby, a ono podnosi rękę, gdy usłyszy ustaloną wcześniej sylabę. Kolejny sposób wymaga obecności drugiej badającej osoby. Badający podaje sylabę, druga osoba powtarza ją prawidłowo lub błędnie, a dziecko ocenia, czy usłyszało dwa razy to samo czy nie. Trzeci sposób przeprowadzenia próby sylabowej wykorzystuje nagranie. Pacjent słucha par wyrazów wymówionych dwukrotnie tak samo lub inaczej i ocenia, co usłyszał.

Najczęściej stosowana jest ostatnia próba - wyrazowa. Opiera się ona na paronimach różniących się jedną cechą dystynktywną. Do próby wyrazowej wykorzystuje się zamieszczone w książce tablice obrazkowe. Zadaniem dziecka jest wskazanie prawidłowego obrazka odzwierciedlającego usłyszane słowo. Styczek zaznacza przy tym, że konieczne jest zasłonięcie ust przez badającego lub stanięcie za dzieckiem podczas przeprowadzania badania. W teście wykorzystano opozycje dźwięczności, miejsca artykulacji, stopnia zbliżenia narządów mowy, opozycje samogłoskowe oraz pary cech różnych [4].

\section{Słuch fonemowy i fonetyczny. Teoria i praktyka (B. Rocławski, 2010)}

Kolejnym dostępnym testem jest „Słuch fonemowy i fonetyczny. Teoria i praktyka” Bronisława Rocławskiego. Narzędzie przeznaczone jest do badania zarówno dzieci, jak i dorosłych. Obejmuje materiał do badania oraz rozwijania słuchu fonemowego i fonetycznego. Podobnie jak Styczek, Rocławski proponuje w swoim teście próby wyrazowe.

Część pierwsza to trzy rysunki przedstawiające różne zjawiska lub przedmioty. Nazwy dwóch obrazków różnią się między sobą tylko jednym fonemem, nazwa trzeciego ma budowę całkowicie odmienną od dwóch pozostałych.

Część druga zawiera rysunki nazw, których pierwsze sylaby różnią się jednym fonemem (próba sylab nagłosowych). Ta część testu pozwala zbadać opozycje pomiędzy wszystkimi fonemami współczesnej polszczyzny. Podobnie jak u Styczek, badanie polega na wskazywaniu przez pacjenta obrazka, którego nazwę lub pierwszą sylabę nazwy podaje osoba przeprowadzająca badanie [2]. 
Tabela 1. Polskie testy badające umiejętności rozróżniania i identyfikowania dźwięków mowy

Table 1. Polish tests to assess the obility of speech discrimination and identification

\begin{tabular}{|c|c|c|c|}
\hline Nazwa testu & Autor & Przeznaczenie & Opis \\
\hline $\begin{array}{l}\text { Badanie i kształtowanie słuchu } \\
\text { fonematycznego }\end{array}$ & I. Styczek & dzieci & $\begin{array}{l}\text { - próba literowa, } \\
\text { - próba sylabowa, } \\
\text { - próba wyrazowa, } \\
\text { - analiza i synteza }\end{array}$ \\
\hline $\begin{array}{l}\text { Logopedyczny Test Przesiewowy. } \\
\text { Podtest IV - Badanie percepcji } \\
\text { dźwięków mowy (polecenia nr 5, 6) }\end{array}$ & $\begin{array}{l}\text { S. Grabias, } \\
\text { Z. M. Kurkowski, } \\
\text { T. Woźniak }\end{array}$ & 6-14 r.ż. & $\begin{array}{l}\text { - próba wyrazowa, } \\
\text { - analiza głoskowa }\end{array}$ \\
\hline Nieznany Język & M. Bogdanowicz & od 5 r.ż. & $\begin{array}{l}\text { - porównywanie paronimów, } \\
\text { - analiza paronimów, } \\
\text { - analiza sylabowa, } \\
\text { - synteza sylabowa, } \\
\text { - analiza fonemowa, } \\
\text { - synteza fonemowa, } \\
\text { - pamięć fonologiczna }\end{array}$ \\
\hline Skala Pomiaru Percepcji Słuchowej Słów & J. Kostrzewski & dzieci, dorośli & $\begin{array}{l}\text { - próba wyrazowa, } \\
\text { - analiza i synteza }\end{array}$ \\
\hline $\begin{array}{l}\text { Stuch fonemowy i fonetyczny. Teoria } \\
\text { i praktyka }\end{array}$ & B. Rocławski & dzieci, dorośli & - próba wyrazowa \\
\hline $\begin{array}{l}\text { Test do badania stuchu fonematycznego } \\
\text { u dzieci i dorostych }\end{array}$ & $\begin{array}{l}\text { E. Szeląg, } \\
\text { A. Szymaszek }\end{array}$ & starsze dzieci, dorośli & - różnicowanie zdań \\
\hline Test do badania słuchu fonemowego & J. Gruba & dzieci & - próba wyrazowa \\
\hline
\end{tabular}

Tabela 1 sporządzona na podstawie literatury:

- Bogdanowicz M. Diagnoza dysleksji u uczniów klasy III szkoły podstawowej. 2009.

- Grabias S, Kurkowski ZM, Woźniak T. Logopedyczny Test Przesiewowy dla Dzieci w Wieku Szkolnym. Lublin; 2002.

- Gruba J. Test do badania słuchu fonemowego. Gliwice: Wydawnictwo „Komlogo”; 2012.

- Kostrzewski J. Skala pomiaru podstawowych zdolności szkolnych. Warszawa; 1974.

- Kurkowski ZM. Audiogenne uwarunkowania zaburzeń komunikacji językowej. Lublin: Wydawnictwo UMCS; 2013.

- Rocławski B. Słuch fonemowy i fonetyczny. Teoria i praktyka. Glottispol; 2010.

- Styczek I. Badanie i ksztattowanie słuchu fonematycznego. Warszawa: Wydawnictwa Szkolne i Pedagogiczne; 1982.

- Szeląg E, Szymaszek A. Test do badania słuchu fonematycznego u dzieci i dorosłych. Gdańsk: Gdańskie Wydawnictwo Psychologiczne; 2006.

\section{Test do badania słuchu fonematycznego u dzieci i dorosłych (E. Szeląg, A. Szymaszek, 2006)}

Testem opierającym się na różnicowaniu zdań jest „Test do badania słuchu fonematycznego u dzieci i dorosłych” Elżbiety Szeląg i Anety Szymaszek, przeznaczony dla dzieci starszych oraz dorosłych. Składa się ze 106 zdań oraz ilustrujących je obrazków, spośród których 96 zdań stanowi badanie właściwe i zawiera pary słów różniące się jednym fonemem. Pozostałe 10 zdań to przykłady wprowadzające do samego badania.

Wszystkie zdania zostały nagrane na płycie CD i dołączone do książki (w celu zapewnienia powtarzalności materiału). Pary zdań składające się na badanie właściwe przyporządkowane zostały losowo do jednej z dwóch list, zachowując jednakową liczbę opozycji spółgłoskowych w każdej $\mathrm{z}$ nich. Każda z nich zawiera wyrazy kluczowe, różniące się spółgłoskami zwartymi, szczelinowymi i półotwartymi. W obrębie każdej listy zastosowano dwie opozycje cech dystynktywnych: dźwięczna/bezdźwięczna oraz miejsca artykulacji, w wypadku słów (wanna - Hanna) obie te cechy występują łącznie.

Na liście 1. i 2. wszystkie zdania prezentowane są losowo. Dołączony klucz umożliwia szybką analizę wykonanego testu. Listy 3. i 4. mogą być również wykorzystywane w trakcie zajęć terapeutycznych, dotyczących usprawniania różnicowania określonych głosek. Ocena słuchu fonematycznego może więc być przeprowadzana na podstawie zestawu losowego (1. i 2. lista) lub zestawu uporządkowanego (3. i 4. lista). Listę wybieramy w zależności od tego, czy interesuje nas ogólne funkcjonowanie pacjenta czy też określone opozycje fonematyczne.

Właściwe badanie polega na wysłuchaniu przez pacjenta zdania nagranego na $\mathrm{CD}$, a następnie pokazaniu odpowiedniego obrazka przedstawiającego treść usłyszanego zdania. Na zamieszczonym protokole w odpowiedniej rubryce zaznaczamy poprawność odpowiedzi udzielanych przez badanego [5].

\section{Test do badania słuchu fonemowego (J. Gruba, 2012)}

Najnowszą publikacją przeznaczoną do badania różnicowania i identyfikowania dźwięków mowy jest wystandaryzowany Test do badania stuchu fonemowego Joanny Grubej. Paronimy prezentowane są w sposób ujednolicony. Karta zapisu poprawnych i niepoprawnych odpowiedzi umożliwia jednoznaczną interpretację i obliczanie wyników. Normalizacja testu pozwala określić miejsce badanego dziecka w grupie wiekowej. Test przeznaczony jest do badań diagnostycznych, przeprowadzanych przez 
nauczycieli wychowania przedszkolnego i wczesnoszkolnego, pedagogów, psychologów, logopedów, neurologopedów oraz inne osoby zajmujące się oceną słuchu fonemowego u dzieci w wieku przedszkolnym.

Wszystkim dzieciom należy prezentować paronimy w ujednolicony sposób. Do każdego z nich ułożono krótki rymowany dwuwiersz. Badający wypowiada rymowanki $z$ równoczesnym wskazaniem obrazka. Taka forma prezentacji znacznie ułatwia dzieciom identyfikację desygnatów i sprawia, że wszystkie dzieci w jednakowy sposób zapoznawane są ze znaczeniem obrazków [7].

\section{Skala Pomiaru Percepcji Słuchowej Słów (J. Kostrzewski, 1974)}

Wśród testów psychologicznych można także znaleźć te do badania słuchu fonematycznego. Jednym z nich jest Skala Pomiaru Percepcji Słuchowej Słów Janusza Kostrzewskiego. Składa się ona z trzech podtestów. Słuchowe różnicowanie głosek (rozróżnianie par wyrazów znaczących lub bez znaczenia) służy do badania słuchu fonematycznego. Użyto w niej takich paronimów jak np. panna-wanna, bułka-półka, bąk-pąk. Badanie polega na określeniu przez dziecko, czy podawane przez osobę dorosłą pary wyrazów brzmią tak samo czy inaczej. Do testu dołączone są normy wiekowe, do których należy się odnieść po przeprowadzeniu badania, aby porównać uzyskane wyniki i ustalić poziom ewentualnych opóźnień [8].

\section{Nieznany język - próby do badania kompetencji fonologicznej (M. Bogdanowicz, 2009)}

Innym testem psychologicznym badającym słuch fonematyczny jest Nieznany język - próby do badania kompetencji fonologicznej Marty Bogdanowicz. Mierzy on m.in. różnicowanie głosek (słuch fonemowy) - w próbie Porównywanie Paronimów. Materiał zawarty w teście to pseudosłowa (wyrazy bezsensowne).

Porównywanie paronimów to część złożona z 25 par wyrazów różniących się tylko jedną głoską. Osoba badająca mówi dwa wyrazy, a dziecko porównuje, czy słyszy takie same słowa czy różne. $\mathrm{W}$ przypadku różnego brzmienia wyrazów dzieci w wieku szkolnym mają podać parę głosek, którymi różnią się słowa [9].

\section{Logopedyczny Test Przesiewowy dla Dzieci w Wieku Szkolnym (S. Grabias, Z. M. Kurkowski,} T. Woźniak, 2002)

Kolejną publikacją, wykorzystującą badanie słuchu fonematycznego jako element składowy całościowego badania logopedycznego, jest Logopedyczny Test Przesiewowy dla Dzieci w Wieku Szkolnym autorstwa Stanisława Grabiasa, Zdzisława Kurkowskiego i Tomasza Woźniaka. Ocenia on sprawność językową dzieci w wieku 6;1-14;11 lat, wystandaryzowany w grupie 1800 dzieci w wieku 6-14 lat.

Oceny dyskryminacji słuchowej dokonuje się na podstawie podtestu IV - Badanie percepcji dźwięków mowy. Próba 5 polega na ocenie przez dziecko, czy podane przez logopedę pary wyrazów są takie same czy inne. W teście użyto pseudosłów [10].
W literaturze anglojęzycznej dostępnych jest kilkanaście testów służących do badania dyskryminacji słuchowej. Wśród dwóch najczęściej stosowanych wymienia się: Wepman's Auditory Discrimination Test (WADT) oraz Goldman-Fristoe-Woodcock Test of Auditory Discrimination.

\section{Wepman's Auditory Discrimination Test (WADT) (J. M. Wepman, W. M. Reynolds, 1987)}

Wepman's Auditory Discrimination Test (WADT), autorstwa Josepha M. Wepmana, Williama M. Reynoldsa, pierwszy raz został opublikowany w 1958 roku, następną poprawioną wersję wydano w 1973 roku. Test ten przeznaczony jest dla dzieci w wieku od czwartego do ósmego roku życia i mierzy zdolności rozpoznawania niewielkich różnic pomiędzy angielskimi fonemami. Składa się z 40 par wyrazów mających taką samą długość. Dziesięć par wyrazów to pary identyczne, trzydzieści pozostałych par różni się między sobą jednym fonemem.

W skład testu wchodzą pary wyrazów:

- 3 pary wyrazów różniących się spółgłoskami nagłosowymi, np. „coast”, „toast”;

- 4 pary wyrazów różniących się samogłoskami śródgłosowymi, np. "pat”, "pet”;

- 13 par wyrazów różniących się spółgłoskami wygłosowymi, np. „lease”, „leash”;

- 10 par wyrazów takich samych, np. ,jam”, ,jam”.

Badanie przeprowadzane jest indywidualnie $\mathrm{z}$ dzieckiem przez logopedę lub pedagoga. Dziecko powinno siedzieć tak, aby nie widzieć zarówno ust osoby badającej, jak i wyrazów zapisanych w teście. Badający czyta pary wyrazów tylko raz, zadaniem dziecka jest odpowiedzieć, czy usłyszane słowa są takie same czy różne. Przeprowadzenie testu trwa od pięciu do dziesięciu minut. Uzyskane wyniki można porównać z załączonymi normami określającymi poziom kompetencji - od bardzo dobrego poziomu rozwoju dziecka do poziomu poniżej normy dla danego wieku. Dwa równorzędne rodzaje testu (formularz 1 oraz formularz 2) można wykorzystać do ponownego badania dziecku w przypadku, gdy ich początkowy wynik wydaje się wątpliwy lub gdy chcemy sprawdzić efekt terapii [11].

Wepman's Auditory Discrimination Test jest wystandaryzowany i uznaje się go za rzetelny i poprawny. Normy zostały wyznaczone na podstawie wyników dwóch tysięcy przebadanych dzieci. WADT to niedrogie i szybkie narzędzie przesiewowe, którego celem jest wyłonienie grupy dzieci mających trudności z dyskryminacją słuchową i których umiejętności słuchowe rozwijają się znacznie wolniej niż w przypadku ich rówieśników. Wykorzystuje się go także w badaniu dzieci mających trudności z nauką czytania oraz jako część oceny umiejętności czytania [11].

\section{Goldman-Fristoe-Woodcock Test of Auditory Discrimination (GFW) (R. Goldman, M. Fristoe, R. W. Woodcock, 1970)}

Kolejnym, stosunkowo często wykorzystywanym testem jest Goldman-Fristoe-Woodcock Test of Auditory Discrimination (GFW). Służy on do oceny wymowy oraz zdolności dyskryminacji słuchowej. Przeznaczony jest do badania pacjentów w wieku od 4. do 70. roku życia i jest testem 
obrazkowym. Polega na odsłuchaniu prezentowanych słów na tle zagłuszającego szumu oraz bez niego. Zadaniem pacjenta jest wskazanie prawidłowego obrazka odzwierciedlającego usłyszane słowo. Test składa się z trzech części prezentowanych obuusznie. Pierwsza - wstępna - zapoznaje z procedurą badania oraz obrazkami wykorzystywanymi w dalszej części testów. Druga część jest testem, podczas którego prezentowane są słowa bez obecności szumu, trzecia część to wykorzystanie tych samych słów na tle hałasu (szumu kawiarnianego). Do wszystkich podtestów dołączone są opracowane normy w odniesieniu do wieku badanego [12].

\section{Auditory Phoneme Sequencing Test (APST) \\ A ten-minute test of auditory discrimination and sequencing (J. Aten, D. Ross-Swain, 1979)}

Auditory Phoneme Sequencing Test (APST) A ten-minute test of auditory discrimination and sequencing autorstwa Jima Atena i Deborah Ross-Swain przeznaczony jest do indywidualnej oceny dzieci w wieku od piątego do dziewiątego roku życia i pozwala na szybką ocenę (10 minut) ich zdolności dyskryminacji słuchowej. APST może być przydatny specjalistom $\mathrm{w}$ zidentyfikowaniu dzieci $\mathrm{z}$ trudnościami w dyskryminacji fonemów i pamięci słuchowej, które to umiejętności są niezbędne do rozumienia i nabywania zdolności językowych oraz rozwijania zdolności pisania i zapamiętywania, a także adekwatnego wykorzystywania informacji odebranych słuchowo. Test ten jest znormalizowany i bazuje na wynikach przeprowadzonych na 750 pacjentach. APST to test obrazkowy. Dwadzieścia elementów jest prezentowanych z płyty $\mathrm{CD}$, podzielonych pomiędzy serie dwóch, trzech, czterech oraz pięciu słów. Dziecko proszone jest o wskazanie obrazków prezentujących usłyszane słowa. Wszystkie wyrazy użyte w teście są jednosylabowe. Nie ma wyznaczonego czasu, w którym należy się zmieścić, przeprowadzając test, jednak zakłada się, że zajmuje on około 10-12 minut. Osiągnięty wynik można porównać $\mathrm{z}$ zamieszczonymi w publikacji normami wiekowymi [13].

\section{Auditory Discrimination and Lip Reading Skills Inventory $^{\text {tim }}\left(\right.$ ADLR $\left.^{\mathrm{mw}}\right)$ (S. McFadin, 2006)}

Auditory Discrimination and Lip Reading Skills Inventory ${ }^{\text {Tw }}$ $\left(\mathrm{ADLR}^{\mathrm{m}}\right)$ ocenia umiejętności, które są potrzebne w dyskryminacji mowy na poziomie słów i zdań. Pomaga zmierzyć aktualny poziom umiejętności w tym zakresie, wyznaczyć cele terapii oraz monitorować postępy. Formularze oceniające postęp dostępne są na załączonej płycie CD. ADLR składa się z sześciu podtestów i czterech arkuszy z pytaniami obserwacyjnymi. Podczas testu pacjent słucha słów lub zdań i musi wskazać odpowiednie jedno lub dwa zdjęcia lub zdania. Z każdym podtestem stopniowo zwiększa się poziom trudności zadań.

Podtesty zamieszczone w publikacji:

1) struktura sylabowa (słowa, które mają różną liczbę sylab, oraz słowa, które mają taką samą liczbę sylab),

2) słowa mające podobną strukturę (dust/dark, stick/duck),

3) słowa różniące się głoską w nagłosie (big/dig, hair/pair),

4) pary słów różniące się dźwięcznością (pat/bat),

5) pary słów różniące się samogłoskami (sit/suit, hit/heat),

6) zdania (mające różną liczbę sylab oraz długość) [14].
Lindamood Auditory Conceptualization Test - Third Edition (LAC-3) (P. C. Lindamood, P. Lindamood, 2005)

Lindamood Auditory Conceptualization Test - Third Edition (LAC-3), autorstwa Patricii C. Lindamood and Phyllis Lindamood, to test przeznaczony do badania dzieci w wieku od 5 do 18 roku życia. Mierzy zdolność dostrzegania oraz analizowania dźwięków mowy przy użyciu wizualnych materiałów. Za jego pomocą można zmierzyć zdolności do odróżniania i identyfikowania dźwięków, które, jeśli są wykształcone właściwie, dają podstawy do nauki prawidłowego czytania oraz literowania. Dostępne są dwie wersje językowe testu: angielska i hiszpańska. Do testu wykorzystywane są dołączone kolorowe klocki oraz kolorowe filcowe elementy. Osiągnięte wyniki można porównać z normami rozwojowymi dołączonymi do testu.

\section{Podtesty wchodzące w skład LAC-3:}

\section{Isolated Phoneme Patterns}

Do tej próby używa się dołączonych do testu kolorowych klocków, każdy kolor oznacza inny fonem. Badany ocenia usłyszany fonem, przesuwając odpowiedni kolor (odpowiadający fonemowi) do przodu, np. jeśli dziecko usłyszy „Pokaż mi /f/ /a/", powinno przesunąć do przodu klocki odpowiadające tym fonemom.

\section{Tracking Phonemes}

Używa się w nim klocków z poprzedniego zadania, które będą potrzebne do tworzenia i modyfikowania nonsensownych wyrazów. Badający dobiera odpowiednie klocki i układa $z$ nich wyraz np. „sasp”, prosi jednocześnie dziecko, aby dołożyło właściwy klocek tak, by powstał wyraz „slasp”.

\section{Counting Syllables}

Kolorowe filcowe elementy układa się przed dzieckiem. Każdy kolor reprezentuje jedną sylabę. Zadaniem dziecka jest odnalezienie odpowiednich elementów, które odpowiadają podanemu nonsensownemu wyrazowi. Jeśli badający mówi „bifter”, badany powinien wskazać odpowiednie dwa elementy odpowiadające sylabom w podanym wyrazie.

\section{Tracking Syllables}

Zadanie analogiczne do podtestu Tracking Phonemes, tylko z użyciem sylab. Kolorowe filcowe elementy odpowiadają sylabom. Pacjent musi tak zmienić ich ułożenie, aby $\mathrm{z}$ jednego nonsensownego wyrazu powstał drugi. Badający układa kolorowe elementy składające się np. na wyraz "pretive” i prosi dziecko o taką manipulację nimi, aby powstał wyraz ,intive”.

\section{Tracking Syllables and Phonemes}

Zadanie wykorzystujące wszystkie poprzednie próby. Pacjent musi odpowiednio ułożyć kolorowe klocki oraz filcowe elementy, aby powstało właściwie słowo [15]. 


\section{Ohio Tests of Articulation and Perception of Sounds (OTAPS) (Irivin, Abbate)}

Podtesty V-VIII zawarte w Ohio Tests of Articulation and Perception of Sounds (OTAPS) wykorzystuje się do badania zdolności dyskryminacji 67 fonemów usłyszanych w wyrazach lub w parach wyrazów. Test jest przeznaczony dla dzieci w wieku 5-8 lat. Ocenia dyskryminację słuchową wyrazów wypowiedzianych zarówno przez drugą osobę, jak i przez samego pacjenta. Badany sam musi określić, czy wypowiada wyrazy prawidłowo czy nie. Autor testu podkreśla, jak ważna w terapii logopedycznej jest percepcja własnych wypowiedzi oraz ich właściwa ocena.

\section{Podtest V}

Służy do oceny percepcji dźwięków mowy. Zadaniem dziecka jest wskazanie odpowiedniego obrazka i określenie, czy badający wypowiedział słowo dobrze czy źle. W tej próbie wykorzystywane są pojedyncze słowa.

\section{Podtest VI}

Badający wypowiada pary wyrazów, dziecko ocenia, czy są one takie same czy różne.

\section{Podtest VII}

Próba wykorzystuje percepcję wypowiedzi pacjenta. Dziecko musi nazwać obrazki, a następnie ocenić, czy wypowiedziało słowa dobrze czy źle.

\section{Podtest VIII}

Ocena własnej wypowiedzi. Badający dwukrotnie wypowiada określone słowo, zadaniem dziecka jest je powtórzyć i porównać, czy zostało wypowiedziane tak samo jak przez badającego [16].

\section{Templin Picture Sound Discrimination Test (M. Templin, 1957)}

Pierwsza wersja Templin Picture Sound Discrimination Test wydana została w 1943 roku i przeznaczona jest dla dzieci 3-5-letnich. Zadaniem badanych była ocena usłyszanych par wyrazów różniących się jednym fonemem (tzw. minimal pairs). Do badania użyto 59 angielskich jednosylabowych par wyrazów zaprezentowanych na obrazkach jako takie same lub różne. Oceniano fonemy w nagłosie, śródgłosie oraz wygłosie wyrazów.

Druga wersja testu, wydana w 1957 roku, przeznaczona jest do badania dzieci w wieku 6-8 lat. Templin użyła w nim nonsensownych sylab składających się ze spółgłoski w nagłosie oraz samogłoski w wygłosie oraz odwrotnie. Zadaniem pacjenta jest ocena dwóch usłyszanych sylab, czy są takie same czy różne [17].

\section{Screening Test for Auditory Perception (STAP) (Klimmel \& Wahl, 1969)}

Screening Test for Auditory Perception (STAP) to narzędzie składające się z pięciu podtestów, przeznaczone do badania dzieci od 2 do 6 klasy szkoły podstawowej.
Pierwsza próba ocenia zdolność pacjenta do wysłyszenia różnic pomiędzy długimi a krótkimi samogłoskami. Badający podaje badanemu pojedyncze słowa. Gdy dziecko usłyszy krótką samogłoskę w wyrazie, stawia żółtą kreskę, a jeżeli długą - pomarańczową.

Druga próba bada zdolność różnicowania spółgłosek - pojedyncza-podwójna. Dziecko musi narysować żółte koło, jeśli usłyszane słowo zaczyna się od spółgłoski pojedynczej, a pomarańczowe, jeśli zaczyna się od podwójnej.

Trzecia próba ocenia umiejętność dobierania rymujących się wyrazów. Dziecko musi zaznaczyć jeden z trzech kolorowych trójkątów, wybierając wyraz, który rymuje się $\mathrm{z}$ usłyszanym.

Czwarta próba bada umiejętność zapamiętywania rytmu. Dziecku prezentowana jest sekwencja trzech stuknięć, badany ma zaznaczyć jedno z trzech kolorowych kół odzwierciedlających usłyszaną sekwencję.

Piąta próba polega na ocenie przez dziecko, czy para usłyszanych wyrazów jest taka sama czy różna. Jeżeli taka sama, dziecko ma postawić pomarańczową kreskę, jeżeli różna - żółtą [16].

Przedstawione powyżej anglojęzyczne testy są narzędziami najczęściej wykorzystywanymi do oceny dyskryminacji słuchowej dzieci i dorosłych. Poniżej przedstawiono szerszy zbiór anglojęzycznych testów dostępnych w literaturze (tabela 2 ).

\section{Wybrane metody terapii}

U większości dzieci nie występują problemy ze słuchem fonematycznym, jednak u niektórych proces ten kształtuje się znacznie wolniej, a część z nich bez długotrwałej i systematycznej terapii nigdy nie osiągnie takiego samego poziomu jak ich rówieśnicy.

Zaburzenia słuchu fonematycznego utrudniają odbiór mowy, jej rozwój oraz powodują trudności w nabywaniu umiejętności czytania i pisania. Prawidłowo funkcjonujący słuch fonematyczny często warunkuje powodzenie terapii logopedycznej, np. w przypadku sygmatyzmu, rotacyzmu czy innych wad wymowy. Stan słuchu fonematycznego w dużej mierze zależy od samego treningu słuchowego, a na jego poprawę mają wpływ także ćwiczenia ortofoniczne i muzyczne [2].

\section{Logopedyczne i pedagogiczne treningi słuchowe}

W praktyce logopedycznej i pedagogicznej wykorzystuje się głównie indywidualnie dobrane i opracowane treningi słuchowe, bazujące na ćwiczeniach dostępnych w polskiej literaturze. Praktycy sięgają głównie do literatury pedagogicznej, przedstawiającej ćwiczenia usprawniające różne funkcje poznawcze. Niestety, zdarza się, że ćwiczenia zawarte w takich publikacjach nie zawsze są rzeczywiście ćwiczeniami usprawniającymi słuch fonematyczny. W związku z tym trzeba podchodzić do nich ostrożnie i rozważyć ich stosowanie, biorąc pod uwagę wiedzę teoretyczną. Należy również zastanowić się, czym właściwie jest słuch fonematyczny, mylony bardzo często $\mathrm{z}$ umiejętnościami z zakresu analizy i syntezy słuchowej. 
Tabela 2. Testy anglojęzyczne

Table 2. English-language tests

\begin{tabular}{|c|c|c|c|}
\hline Nazwa testu & Autor & Przeznaczenie & Opis \\
\hline $\begin{array}{l}\text { Auditory Discrimination and Lip } \\
\text { Reading Skills Inventory }{ }^{T M}\left(A D L R^{T M}\right)\end{array}$ & Shelley McFadin & dzieci & $\begin{array}{l}\text { - ocenia umiejętności dyskryminacji } \\
\text { słuchowej na poziomie wyrazów } \\
\text { i zdań }\end{array}$ \\
\hline $\begin{array}{l}\text { Auditory Phoneme Sequencing Test } \\
\text { (APST) }\end{array}$ & $\begin{array}{l}\text { Jim Aten, Deborah } \\
\text { Ross-Swain }\end{array}$ & 5-9 r. ż. & $\begin{array}{l}\text { - pozwala na szybką ocenę (10 minut) } \\
\text { zdolności dyskryminacji słuchowej, } \\
\text { - dźwięki nagrane na płycie CD, } \\
\text { - dziecko wskazuje obrazek ilustrujący } \\
\text { usłyszane słowo }\end{array}$ \\
\hline $\begin{array}{l}\text { Boston University Speech-Sound } \\
\text { Discrimination Picture Test }\end{array}$ & $\begin{array}{l}\text { Pronovost \& } \\
\text { Dumbleton, } 1953 \text {, } \\
\text { wznowienie } \\
\text { Pronovost, } 1974\end{array}$ & $\begin{array}{l}\text { dzieci w wieku } \\
\text { przedszkolnym do } \\
\text { pierwszej klasy szkoły } \\
\text { podstawowej }\end{array}$ & $\begin{array}{l}\text { - pary słów jednosylabowych, } \\
\text { - dziecko musi wskazać prawidłową } \\
\text { parę obrazków spośród trzech do } \\
\text { wyboru }\end{array}$ \\
\hline $\begin{array}{l}\text { Goldman-Fristoe-Woodcock Test of } \\
\text { Auditory Discrimination (GFW) }\end{array}$ & $\begin{array}{l}\text { Goldman, Fristoe } \\
\text { \& Woodcock }\end{array}$ & 3,8 r.ż. - dorośli & $\begin{array}{l}\text { - test dyskryminacji słuchowej (w ciszy } \\
\text { oraz z sygnałem zagłuszającym) }\end{array}$ \\
\hline $\begin{array}{l}\text { Goldman-Fristoe-Woodcock Test of } \\
\text { Auditory Skills Battery }\end{array}$ & $\begin{array}{l}\text { Goldman, Fristoe } \\
\& \text { Woodcock }\end{array}$ & 3,8 r.ż. - dorośli & $\begin{array}{l}\text { - test umiejętności słuchowych } \\
\text { obejmujący m.in.: } \\
\text { - test uwagi słuchowej, } \\
\text { - test dyskryminacji słuchowej, } \\
\text { - test pamięci słuchowej }\end{array}$ \\
\hline Kindergarten Auditory Screening Test & Katz, 1971 & $\begin{array}{l}\text { dzieci w wieku } \\
\text { przedszkolnym }\end{array}$ & $\begin{array}{l}\text { - test rozumienia mowy w hałasie, } \\
\text { - test dyskryminacji słuchowej (pary } \\
\text { wyrazów) }\end{array}$ \\
\hline $\begin{array}{l}\text { Lindamood Auditory Conceptualization } \\
\text { Test (LAC) } \\
\text { Lindamood Auditory Conceptualization } \\
\text { Test - Third Edition (LAC-3) }\end{array}$ & $\begin{array}{l}\text { Lindamood \& } \\
\text { Lindamood, } 1971, \\
\text { wznowienie w 1979, } \\
\text { Lindamood \& } \\
\text { Lindamood, } 2004\end{array}$ & 5-18 r.ż. & $\begin{array}{l}\text { - test dyskryminacji słuchowej } \\
\text { (zadania na pojedynczych głoskach, } \\
\text { sylabach i wyrazach) }\end{array}$ \\
\hline $\begin{array}{l}\text { Northwestern University Children's } \\
\text { Perception of Speech Test (NU-CHIPS) }\end{array}$ & Elliott \& Katz, 1980 & dzieci & $\begin{array}{l}\text { - obrazkowy test dyskryminacji } \\
\text { słuchowej, } \\
\text { - jednosylabowe wyrazy różniące się } \\
\text { jednym fonemem, } \\
\text { - dziecko wybiera spośród czterech } \\
\text { możliwych obrazków }\end{array}$ \\
\hline $\begin{array}{l}\text { Ohio Tests of Articulation and } \\
\text { Perception of Sounds (OTAPS) }\end{array}$ & Irivin \& Abbate, 1973 & 5-8 r.j. & $\begin{array}{l}\text { - testy oceniające artykulację oraz } \\
\text { umiejętności słuchowe (podtesty } \\
\text { V-VIII) }\end{array}$ \\
\hline Picture Sound Discrimination Test & Templin, 1943 & 3-5 r.ż. & $\begin{array}{l}\text { - obrazkowy test dyskryminacji } \\
\text { słuchowej (dziecko ocenia, czy } \\
\text { usłyszane jednosylabowe wyrazy są } \\
\text { takie same czy różne) }\end{array}$ \\
\hline Picture Speech Discrimination Test & Mecham \& Jex & dzieci i dorośli & $\begin{array}{l}\text { - obrazkowy test dyskryminacji } \\
\text { słuchowej, } \\
\text { - obrazki dobrane na podstawie } \\
\text { Thorndike List }\end{array}$ \\
\hline $\begin{array}{l}\text { Prognostic Value of Imitative and } \\
\text { Auditory Discrimination Test }\end{array}$ & Farquhar & $\begin{array}{l}\text { dzieci w wieku } \\
\text { przedszkolnym }\end{array}$ & $\begin{array}{l}\text { - test powtarzania dźwięków, sylab } \\
\text { i wyrazów nonsensownych, } \\
\text { - test słuchania i oceny usłyszanego } \\
\text { materiału „takie same”, „różne” }\end{array}$ \\
\hline $\begin{array}{l}\text { Robbins Speech Sound Discrimination } \\
\text { and Verbal Imagery Type Tests }\end{array}$ & $\begin{array}{l}\text { Samuel Dowse } \\
\text { Robbins, Rosa } \\
\text { Seymour Robbins, } \\
1958\end{array}$ & 4-8 r.j̇. & - ocena dyskryminacji słuchowej \\
\hline $\begin{array}{l}\text { Schiefelbush-Lindsey Test of Sound } \\
\text { Discrimination }\end{array}$ & $\begin{array}{l}\text { Schiefelbusch \& Mary } \\
\text { Jeanne Lindsey, } 1958\end{array}$ & $\begin{array}{l}1-2 \text { klasa szkoły } \\
\text { podstawowej }\end{array}$ & $\begin{array}{l}\text { - trzy części: jak dziecko słyszy mowę } \\
\text { innych, jak słyszy mowę własną } \\
\text { oraz jak cichą mowę jest w stanie } \\
\text { zrozumieć }\end{array}$ \\
\hline Screening Test for Auditory Perception & Klimmel \& Wahl, 1969 & $\begin{array}{l}\text { 2-6 klasa szkoły } \\
\text { podstawowej }\end{array}$ & $\begin{array}{l}\text { - pięć podtestów badających } \\
\text { umiejętności słuchowe }\end{array}$ \\
\hline Short Test of Sound Discrimination & Templin, 1957 & 6-8 r.j. & $\begin{array}{l}\text { - nonsensowne pary sylab, } \\
\text { - dziecko ocenia, czy usłyszane pary } \\
\quad \text { sylab są takie same czy różne }\end{array}$ \\
\hline
\end{tabular}




\begin{tabular}{|c|c|c|c|}
\hline Nazwa testu & Autor & Przeznaczenie & Opis \\
\hline $\begin{array}{l}\text { Test of Auditory Processing Skills } \\
\text { - Third Edition (TAPS-3) }\end{array}$ & $\begin{array}{l}\text { Martin \& Brownell, } \\
2005\end{array}$ & 4-8 r.ż. & $\begin{array}{l}\text { - bateria testów oceniająca zdolności } \\
\text { słuchowe, } \\
\text { - zawiera dziewięć podtestów, w tym } \\
\text { badanie dyskryminacji słuchowej } \\
\text { wyrazów }\end{array}$ \\
\hline $\begin{array}{l}\text { Test of Language Development (TOLD) } \\
\text { Test of Language Development-Primary } \\
\text { (TOLD-P: } 3 \text { ) } \\
\text { Test of Language Development-Primary } \\
\text { (TOLD-P: } 4 \text { ) }\end{array}$ & $\begin{array}{l}\text { Newcomer \& Hammil, } \\
1977 \\
\text { Newcomer \& Hammil, } \\
1997 \\
\text { Newcomer \& Hammil, } \\
2008\end{array}$ & 4-8 r.ż. & $\begin{array}{l}\text { - bateria testów badających zdolności } \\
\text { językowe, } \\
\text { - zawiera podtest dotyczący } \\
\text { dyskryminacji słuchowej, } \\
\text { - pary wyrazów, } \\
\text { - dziecko ocenia, czy usłyszane słowa } \\
\text { są takie same czy różne }\end{array}$ \\
\hline $\begin{array}{l}\text { Test of Nonverbal Auditory } \\
\text { Discrimination (TENVAD) }\end{array}$ & Buktenica, 1968 & 6-8 r.ż. & $\begin{array}{l}\text { - } 50 \text { par tonów (10 par różniących się: } \\
\text { wysokością, natężeniem, czasem } \\
\text { trwania, rytmem, barwą), } \\
\text { - dźwięki odtwarzane z CD, } \\
\text { - dziecko musi ocenić, czy usłyszane } \\
\text { pary tonów są takie same czy różne }\end{array}$ \\
\hline $\begin{array}{l}\text { The Auditory Discrimination and } \\
\text { Attention Test }\end{array}$ & $\begin{array}{l}\text { Rosemarie } \\
\text { Morgan-Barry, } 1988\end{array}$ & 3-12 r.ż. & $\begin{array}{l}\text { - } 17 \text { par wyrazów różniących się } \\
\text { jednym fonemem (minimal pairs), } \\
\text { - dziecko nazywa obrazki, następnie } \\
\text { wskazuje obrazek, którego nazwa } \\
\text { została wypowiedziana przez } \\
\text { badającego }\end{array}$ \\
\hline $\begin{array}{l}\text { Travis-Rasmus Speech Sound } \\
\text { Discrimination Test }\end{array}$ & Travis \& Rasmus, 1931 & 5 r.ż. - dorośli & $\begin{array}{l}\text { - test oceny dyskryminacji słuchowej } \\
\text { słów, } \\
\text { - używany przede wszystkim } \\
\text { w przypadku występowania wady } \\
\text { wymowy, } \\
\text { - pary nonsensownych sylab, } \\
\text { - badany ocenia, czy usłyszane pary } \\
\text { sylab są takie same czy różne }\end{array}$ \\
\hline $\begin{array}{l}\text { Washington Speech Sound } \\
\text { Discrmination Test (WSSD) }\end{array}$ & $\begin{array}{l}\text { Prather, Miner, } \\
\text { Addicott \& } \\
\text { Sunderland }\end{array}$ & $\begin{array}{l}\text { od } 3 \text { r.ż. - do wieku } \\
\text { przedszkolnego }\end{array}$ & $\begin{array}{l}\text { - test dyskryminacji słuchowej } \\
\text { - pojedyncze słowa } \\
\text { - dziecko wskazuje obrazek, którego } \\
\text { nazwę usłyszało }\end{array}$ \\
\hline Wepman Auditory Discrimination Test & $\begin{array}{l}\text { Joseph M. Wepman, } \\
\text { William M. Reynolds }\end{array}$ & 4-8 lat & $\begin{array}{l}\text { - } 40 \text { par wyrazów do badania } \\
\text { dyskryminacji słuchowej }\end{array}$ \\
\hline $\begin{array}{l}\text { Word Intelligibility by Picture } \\
\text { Identification (WIPI) }\end{array}$ & Ross \& Lerman & dzieci & $\begin{array}{l}\text { - test dyskryminacji słuchowej dla } \\
\text { dzieci z uszkodzonym narządem } \\
\text { słuchu }\end{array}$ \\
\hline
\end{tabular}

Tabela 2 sporządzona na podstawie literatury:

- Beech JR, Harding L, Hilton-Jones D. Assessment in Speech and Language Therapy. 1993.

- Eisenberg LS, Johnson KC, Martinez AS. Clinical Assessment of Speech Perception for Infants and Toddlers. 2005.

- Geffner D, Ross-Swain D. Auditory Processing Disorders. Assessment, Management and Treatment. Second Edition. 2013.

- Johnson CD, Seaton JB. Educational Audiology Handbook. Second Edition. 2012.

- Lass NJ. Speech and Language Advances in Basic Research and Pracitce. Volume 6; 1981.

- Nicolosi L, Harryman E, Kresheck J. Terminology of Communication Disorders. Speech-Language-Hearing. Fifth Edition. 2004.

- Reynolds CR, Fletcher-Janzen E. Concise Encyclopedia of Special Education. A reference for the Education of the Handicapped and Other Exceptional Children and Adults. 2002.

Propozycje ćwiczeń usprawniających słuch fonematyczny można znaleźć w podręcznikach przeznaczonych głównie do diagnozy, tzn. Rocławskiego „Poradnik fonetyczny dla nauczycieli”, „Słuch fonemowy i fonetyczny. Teoria i praktyka” oraz Styczek „Badanie i kształtowanie słuchu fonematycznego". Inne ćwiczenia prezentuje w swoich publikacjach Cieszyńska.

Wśród pozycji skoncentrowanych na usprawnianiu funkcji słuchowych należy wymienić publikacje Löwe „Rozwijanie słuchu w zabawie” oraz Maurer „Dźwięki mowy. Program kształtowania świadomości fonologicznej dla dzieci przedszkolnych i szkolnych".

Zestaw ćwiczeń do terapii słuchu fonemowego dla pacjentów $\mathrm{z}$ afazją można znaleźć w wydawnictwie „Dać rzeczy słowo. Słuch fonemowy" Litwin, Pietrzyk.

Na polskim rynku dostępne są również publikacje multimedialne przeznaczone do treningu słuchowego, w tym słuchu fonematycznego, takie jak „Sfonem” firmy Young Digital Planet oraz „Trening słuchu - naucz się rozróżniać głoski” wydany przez PWN. 


\section{Metoda Warnkego}

Metodą stosunkowo od niedawna praktykowaną w Polsce jest metoda Warnkego, która bazuje na hipotezie, iż problemy z dysleksją wiążą się z zapamiętaniem brzmienia słów, co powoduje trudności z przypisaniem im głosek i liter. Celem metody jest kompleksowa pomoc dzieciom $\mathrm{z}$ dysleksją i trudnościami w nauce, wsparcie terapii logopedycznej, a także diagnostyka i terapia dorosłych z trudnościami w przetwarzaniu bodźców słuchowych.

Metoda opracowana przez Freda Warnkego przeznaczona jest do pracy z dziećmi lub osobami dorosłymi, u których występują trudności w zakresie prawidłowego czytania, pisania i mówienia. Oprócz samych zestawów do terapii dostępne są również materiały ćwiczeniowe, m.in. do usprawniania słuchu fonematycznego, a są nimi np. „Kers a lig” - teksty pozbawione znaczenia. Trening czytania fonematycznego [18].

\section{Metoda Tomatisa}

Tomatis wskazywał na zależność między występującymi u dzieci trudnościami w różnicowaniu wysokości dźwięków a zaburzeniami rozwoju mowy, w szczególności problemami artykulacyjnymi oraz trudnościami w czytaniu i pisaniu. W przypadku stwierdzenia zaburzeń w dyskryminacji wysokości dźwięków proponował zastosowanie opracowanej przez siebie metody, w której wykorzystywał między innymi filtrowane dźwięki w celu pobudzenia umiejętności różnicowania dźwięków. Stosował również odpowiednio dobrane listy słów w celu stymulowania pasm częstotliwości, w których zawarte są cechy dystynktywne istotne dla danego języka.

\section{Stymulator Polimodalnej Percepcji Sensorycznej}

Odpowiednio filtrowane dźwięki muzyki oraz mowy (filtrami górno-, dolno- i środkowoprzepustowymi) mogą być zastosowane $\mathrm{w}$ celu stymulacji dzieci z zaburzeniami wymowy i trudnościami w czytaniu i pisaniu, u których stwierdza się zaburzenia dyskryminacji wysokości dźwięków. Terapia wzbogacona jest o gry komputerowe rozwijające sprawność różnicowania dźwięków ze względu na częstotliwość, czas trwania i głośność.

\section{Wnioski}

Prawidłowo funkcjonujący słuch fonematyczny jest niezbędny w procesie rozwoju i percepcji mowy. W wielu przypadkach to właśnie jego zaburzenia są przyczyną problemów u pacjentów $\mathrm{z}$ wadami wymowy. W związku $\mathrm{z}$ tym w procesie kompleksowej diagnozy niezbędne jest dokładne zbadanie umiejętności słuchowych. Jak napisano w artykule, na polskim rynku jest kilka testów do takiej diagnozy, przeznaczonych zarówno dla dzieci, jak i dla dorosłych. W przypadku usprawniania słuchu fonematycznego dopiero od niedawna stosuje się specjalnie opracowane treningi słuchowe, takie jak m.in. metoda Warnkego, Tomatisa czy Stymulator Polimodalnej Percepcji Sensorycznej. Większość terapeutów w dużej mierze wciąż jednak korzysta $\mathrm{z}$ ćwiczeń dostępnych $\mathrm{w}$ literaturze lub z programów komputerowych przeznaczonych do terapii zaburzeń słuchu fonematycznego.

Artykut powstat $w$ związku $z$ realizacja projektu „Zintegrowany system narzędzi do diagnostyki i telerehabilitacji schorzeń narzqdów zmystów (słuchu, wzroku, mowy, równowagi, smaku, powonienia)" wspólfinansowanego przez Narodowe Centrum Badań i Rozwoju w ramach Programu STRATEGMED".

\section{Piśmiennictwo:}

1. Kania JT. Szkice logopedyczne. Warszawa: WSiP; 1982.

2. Rocławski B. Słuch fonemowy i fonetyczny. Teoria i praktyka. Glottispol; 2010.

3. Kreutzer J, DeLuca J, Caplan B. Encyclopedia of Clinical Neuropsychology. 2011, s. 301-2.

4. Styczek I. Badanie i kształtowanie słuchu fonematycznego. Warszawa: Wydawnictwa Szkolne i Pedagogiczne; 1982.

5. Szeląg E, Szymaszek A. Test do badania słuchu fonematycznego u dzieci i dorosłych. Gdańsk: Gdańskie Wydawnictwo Psychologiczne; 2006.

6. Kurkowski ZM. Audiogenne uwarunkowania zaburzeń komunikacji językowej. Lublin: Wydawnictwo UMCS; 2013.

7. Gruba J. Test do badania słuchu fonemowego. Gliwice: Wydawnictwo „Komlogo”; 2012.

8. Kostrzewski J. Skala pomiaru podstawowych zdolności szkolnych. Warszawa; 1974.

9. Bogdanowicz M. Diagnoza dysleksji u uczniów klasy III szkoły podstawowej. 2009.
10. Grabias S, Kurkowski ZM, Woźniak T. Logopedyczny Test Przesiewowy Dla Dzieci w Wieku Szkolnym. Lublin; 2002.

11. Wepman JM, Reynolds WM. Wepman's Auditory Discrimination Test $^{\mathrm{TM}}$, Second Edition (ADT ${ }^{\mathrm{TM}}$ ). 1987.

12. Goldman R, Fristoe M, Woodcock RW. Goldman Fristoe Woodcock Test of Auditory Discrimination. Circle Pines, MN: American Guidance Service, Inc; 1970.

13. Aten J, Ross-Swain D. Auditory Phoneme Sequencing Test. 1979.

14. McFadin S. Auditory Discrimination and Lip Reading Skills Inventory. 2006.

15. Lindamood P. Lindamood Auditory Conceptualization Test, Third Edition (LAC-3). 2005.

16. Lass NJ. Speech and Language Advances in Basic Research and Practice. Volume 6; 1981.

17. Flottmann F. The influence of aural training in music on the perspective performance of adult learners. Sound discrimination abilities in an unkown foreign language. 2010.

18. biomed.org 